OPEN ACCESS

E-ISSN : 2549-6581

Artikel Hasil Penelitian

Diterima : 21 April 2017

Direview : 28 April 2017

Dimuat : April - Juli 2017
Journal of Issues in Midwifery

\title{
HUBUNGAN POLA ASUH ORANG TUA DENGAN PERKEMBANGAN ANAK PRASEKOLAH PADA IBU YANG MENIKAH DINI DI WILAYAH PUSKESMAS JABUNG
}

\author{
Era Nurisa Windari ${ }^{1}$, Idkha Trisintyandika ${ }^{1}$, Djoko Santoso ${ }^{2}$ \\ ${ }^{1}$ Midwifery Departement, Faculty of Medicine, Universitas Brawijaya, Malang, East Java, Indonesia \\ ${ }^{2}$ Anatomy Laboratory, Faculty of Medicine, Universitas Brawijaya, Malang, East Java, Indonesia \\ Email* : ersawibowo@gmail.com
}

\begin{abstract}
Development can be defined as the increase of abilities or the structuresof skill, and when the functions of the body become more complex. It happens in regular patterns and can be predicted as cell differentiation process of the body when the body's tissues, organs, and the systems are developing in such way that each of them can fulfill its functions. Children development consists of four aspects: gross motor, fine motor, language, and social personality. One thing that influences the development of preschool children are parents' parenting patterns. The age of the mother's marriage also affectsher role in giving the proper parenting patterns to her child. This study aims to determine the connections between parenting patterns andthe development of preschool childrenof mothers who do early marriage in the area of Jabung health centers. The design of the study is observational analytic with cross sectional approach. Samples are selected using the technique of total sampling with a sample of 52 parents and preschool children. The independent variableis the parenting patterns of the mothers who do early marriage and it is measured by questionnaires while the dependent variable is the development of infants measured by Denver II. The results of Chi Square statistical test with $\alpha=0.05$ is obtained $p=0.026$. It means that there is a connection between parenting patterns of the mothers who do early marriage and the development of preschool children. The conclusion of this research is that there is a connection between the parenting patterns and the development of preschoolchildren of the mothers who do early marriage in the area of Jabung health center..
\end{abstract}

Keyword: patterns, development, preschoolers, early marriage

Perkembangan adalah bertambahnya kemampuan atau skill struktur dan fungsi tubuh 
yang lebih kompleks, dalam pola yang teratur dan dapat diramalkan, sebagai proses diferensiasi sel tubuh, jaringan tubuh, organ, dan sistem organ yang berkembang sedemikian rupa sehingga masing-masing dapat memenuhi fungsinya. Perkembangan anak terdiri dari 4 aspek yaitu motorik kasar, motorik halus, bahasa dan personal sosial. Salah satu yang memengaruhi perkembangan anak prasekolah adalah pola asuh orang tua. Usia pernikahan ibu juga berpengaruh dalam perannya memberikan pola pengasuhan yang tepat pada anaknya. Penelitian ini bertujuan untuk mengetahui hubungan pola asuh orang tua dengan perkembangan anak prasekolah pada ibu yang menikah dini di wilayah puskesmas Jabung. Desain penelitian yang digunakan yaitu observational analitik dengan pendekatan cross sectional. Sampel dipilih menggunakan teknik total sampling dengan jumlah sampel sebanyak 52 orang tua dan anak usia prasekolah. Variabel independen yaitu pola asuh orang tua pada ibu yang menikah dini yang diukur dengan menggunakan kuisoner, sedangkan variabel dependennya yaitu perkembangan bayi yang diukur dengan menggunakan Denver II. Hasil uji statistik Chi Square dengan $=0,05$ diperoleh nilai $p=0,026$ maka dapat diartikan bahwa terdapat hubungan antara pola asuh orang tua pada ibu yang menikah dini dengan perkembangan anak prasekolah. Kesimpulan dari penelitian ini yaitu ada hubungan pola asuh orang dengan perkembangan anak prasekolah pada ibu yang menikah dini di wilayah puskesmas Jabung.

Kata kunci: pola asuh orang tua, perkembangan, anak prasekolah, menikah dini

*Korespondensi: Era Nurisa w. Surel: ersawibowo@gmail.com 


\section{PENDAHULUAN}

Remaja merupakan tahapan seseorang dimana seseorang berada diantara fase anak dan dewasa yang ditandai dengan pertumbuhan fisik, perilaku, kognitif, biologis dan emosi.pada remaja putri biasanya ditandai adanya menstruasi pertama kali atau yang disebut menarche. Menurut Menteri Kesehatan RI tahun 2010, batas usia remaja adalah antara 10 sampai 19 tahun dan belum menikah ${ }^{1}$.

Permasalahan kesehatan pada perempuan berawal dari masih tingginya usia perkawinan pertama dibawah 20 tahun. Fakta Indonesia tentang pernikahan dini adalah Indonesia termasuk Negara dengan presentase pernikahan usia muda tertinggi didunia dengan ranking 37, tertinggi kedua di ASEAN setelah Kamboja ${ }^{2}$. Presentasi usia perkawinan pertama dibawah 20 tahun di Indonesia sebesar $4,8 \%$ pada usia $10-14$ tahun, $41,9 \%$ pada usia $15-19$ tahun. Untuk wilayah jawa timur pernikahan usia 10-14 tahun sebesar $6,1 \%$, $15-19$ sebesar 44,5\%. Umur pertama menikah pada usia sangat muda 10-14 tahun cenderung lebih tinggi di pedesaan $6,2 \%$, kelompok perempuan yang tidak sekolah 9,5\%, kelompok petani/nelayan/ buruh $6,3 \%$, serta status ekonomi terendah $6,0 \%$. Semakin tinggi pendidikan persentase usia perkawinan pertama pada usia dini semakin kecil. Hal ini mengindikasikan bahwa pendidikan dapat menunda usia pekawinan ${ }^{3}$.

Pada data kantor pemberdayaaan perempuan dan perlindungan anak kabupaten malang tercatat pada tahun 2012 untuk usia menikah pada anak usia 9 sampai 16 tahun sebanyak 225 laki-laki dan perempuan, pada usia 16 sampai 18 tahun sebanyak 6278 dan kurang dari 20 tahun sebanyak 8515 terdari laki-laki dan perempuan. Sedangkan, pada wilayah Jabung menurut data departemen agama jumlah pernikahan pada tahun 2012 sebesar 726 dengan 602 yang menikah pada usia kurang dari 20 tahun $^{4}$.
Salah satu permasalahan yang akan dihadapi dari pernikahan dini adalah cara mendidik anak dengan pola asuh yang tepat dan benar. Hingga saat ini banyak ditemukan kasus yang sering terjadi pada anak dengan orangtua yang menikah di usia muda menjadikan orang tua sebagai sosok yang demokratis, permisif dan otoriter. Sedangkan orangtua yang demokratis atau yang memprioritaskan kepentingan anak sangat jarang ditemukan ${ }^{5}$.

Pada pernikahan dini akan terjadi ketidak stabilan emosi karena kurang siapnya menjadi orang tua padahal orang tua adalah teladan pertama bagi pembentukan kepribadian anak, pemikiran dan prilaku orang tua akan memiliki pengaruh terhadap perkembangan anak. Peran orang tua dalam membesarkan dan membimbing anak berpengaruh besar dalam perkembangan anak ${ }^{6}$.

Orang tua dan pola asuh memiliki peranan yang besar dalam perkembangan anak. Pada awal pertumbuhan, anak membutuhkan bimbingan orang tua dalam hal komunikasi, mendisiplinkan, memonitor, mendorong dan mendidik. Pemberian stimulasi yang benar pada anak yang sesuai dan tepat dengan perkembangan anaknya akan memberikan hasil yang baik pada perkembangan anak tersebut. Demikian dengan pola asuh yang tepat pada anak akan menjadi penentuan perkembangan dan kepribadian seseorang pada masa yang akan datang ${ }^{7}$.

Dari ulasan diatas pada orang tua yang menikah pada usia remaja cenderung memiliki emosi yang tidak stabil dan permasalahan yang sering timbul akibat pernikahan dini adalah bagaimana cara mereka mengasuh anak dengan pola asuh yang tepat. Pemberian pola asuh yang salah atau kurang tepat akan mempengaruhi perkembangan anak. Berdasarkan fakta- fakta diatas perlu diteliti tentang Hubungan Pola Asuh 
Orang Tua dengan Perkembangan Anak Pra-Sekolah pada Ibu yang Menikah Dini di Wilayah Puskesmas Jabung

\section{METODE PENELITIAN Rancangan/Desain Penelitian}

Penelitian yang digunakan dengan desain penelitian analitik observasional melalui metode penelitian cross sectional.

\section{Sumber Data}

Variabel terikat pada penelitian ini adalah prematuritas sedangkan variabel bebas yaitu usia resiko tinggi kurang dari 20 tahun.

\section{Sasaran Penelitian}

Sampel yang digunakan berdasarkan data KUA 2012 didapatkan 52 responden yang menikah di bawah 20 tahun dan diperkirakan mempunyai anak usia prasekolah.

\section{Pengembangan Instrumen dan Teknik Pengumpulan Data}

Pengambilan sampel dengan menggunakan total sampling berdasarkan kriteria inklusi dan eksklusi.

\section{Teknik Analisis Data}

Teknik analisa data menggunakan uji statistik Chi Square dan Uji Beda dengan derajat kepercayaan $95 \%$ dengan $\alpha=0,05$.

\section{HASIL PENELITIAN}

Berdasarkan dari 52 responden yang diteliti pada ibu yang menikah dibawah 20 tahun yang memiliki balita usia prasekolah, frekuensi tertinggi pada pola asuh orang tua adalah pola asuh permisif sebanyak 29 responden (56\%) sedangkan frekuensi terendah pada pola asuh orang tua adalah penelantar sebanyak 2 responden (4\%). Sedangkan untuk pola asuh demokratis sebanyak 7 responden $(13 \%)$ dan pola asuh otoriter sebanyak 14 reponden (27\%).
Diagram: hubungan pola asuh orang tua dengan perkembangan anak prasekolah pada ibu yang menikah dini

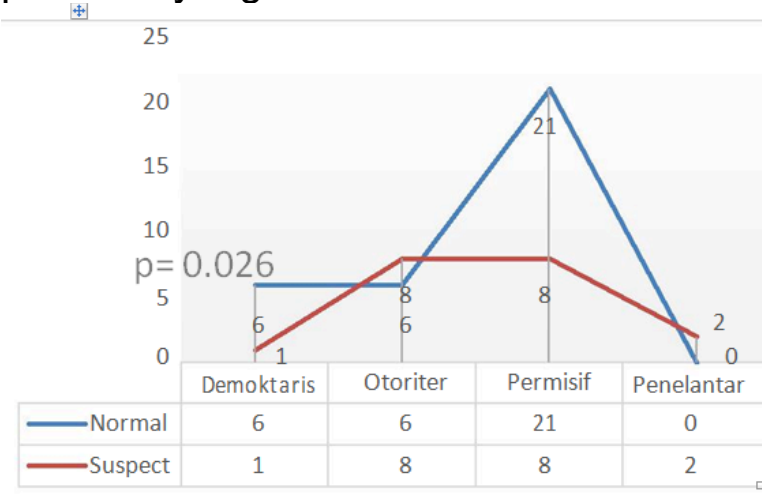

Berdasarkan uji chi square ditemukan 3 cell yang tidak memenuhi syarat untuk menggunakan metode chi square. Turunan dari metode chi square yaitu likelihood ratio diperoleh nilai signifikan 0,026 yang menunjukan bahwa ada hubungan antara pola asuh orang tua dengan perkembangan anak. Nilai signifikan 0,026 artinya untuk pola asuh orang tua demokratis dan permisif perkembangan anak usia prasekolah lebih menunjukkan tingkat perkembagan normal. Sedangkan dengan pola asuh orang tua penelantar dan otoriter perkembangan anak usia prasekolah lebih cenderung menunjukan tingkat perkembangan suspect. Sehingga pada ibu yang menikah dibawah 20 tahun ada hubungan antara pola asuh orang tua dengan perkembangan anak usia prasekolah. Hasil uji statistik diperoleh $p=0,026$ yang berarti $\mathrm{HO}$ ditolak dan $\mathrm{H} 1$ diterima artinya bahwa terdapat perbedaan yang signifikan antara pola asuh orang tua pada ibu yang menikah dibawah 20 tahun dengan perkembangan anak prasekolah.

\section{PEMBAHASAN}

Perekembangan anak sangat dipengaruhi oleh kualitas interaksi anak dan orang tua. Interaksi timbal balik antara anak dan orang tua akan menimbulkan keakraban dalam keluarga. Komunikasi yang baik akan menimbulkan kedekatan dan kepercayaan sehingga hubungan orang tua dan anak akan 
menjadi menyenangkan dan membuat anak terdorong untuk mengembangakan kepripadiannya begitu pula perkembangan anak akan baik ${ }^{8}$.

Hasil analisis hubungan pola asuh orang tua dengan perkembangan anak prasekolah pada ibu yang menikah dini didapatkan nilai signifikansi sebesar 0,026 $<=0,05$. Hal ini menunjukkan bahwa ada hubungan antara pola asuh orang tua dengan perkembangan anak prasekolah pada ibu yang menikah dini. Nilai signifikan 0,026 artinya hubungan pola asuh demokratis dan permisif lebih menunjukkan perkembangan anak normal, sedangkan dengan pola asuh otoriter dan penelantar perkembangan anak lebih cenderung ke suspect.

Perkembangan anak dipengaruhi oleh beberapa faktor, salah satunya ada pola pengasuhan yang diterapkan dalam keluargapada penelitian ini ditemukan ibu yang menikah dibawah 20 tahun sebagian besar menggunkan pol asuh permisif. Sisi positif dari pola asuh permisif pada anak adalah semua perhatian bisa tertujuh pada anak tapii sisi negative dari jenis pola asuh ini jika anak sudah dewasa akan menyebabkan anak kurang bertanggung jawab, mempunyai kendali emosi yang buruk. Sedangkan, anak yang dibesarkan dengan pola asuh yang demokratis mempunya penyesuian pribadi dan sosial yang lebih baik, anak lebih mandiri dan bertanggung jawab ${ }^{2}$.

Hasil analisis juga menunjukkan bahwa orang tua yang mengasuh anaknya dengan pola asuh penelantar anak akan memiliki perkembangan yang cenderung suspect. Penelitian yang dilakukan Kusumawardani (2015) juga menggungkapkan bahwa pada pola asuh penelantar orang tua tidak memberikan viiontrol dan kendali serta tidak memberikan kasih sayang kepada anak sehingga cenderung membiarkan anak tanpa memenuhi kebutuhan fisik dan psikis anak. Orang tua yang tidak memperhatikan anaknya akan membuat perkembangan anak terlambat.
Pada penelitian ini juga ditemukan orang tua yang berpola asuh otoriter anak cenderung memiliki perkembangan Suspect. Hal ini Karena pada pola asuh otoriter sikap demokratis orang tua serta kasih sayang orang tua sangat rendah, orang tua hanya memberikan kendali penuh dan tuntutang prestasi yang tinggi. Pemberian tuntutan prestasi yang tinggi juga tidak diseimbangkan dengan kasih sayang orang tua itu akan membuat anak merasa tertekan dan membuat anak tidak memiliki dorongan untuk berprestasi.

Selain pola asuh orang tua dan kualitas interaksi orang tua- anak, pendidikan, jenis kelamin, jumlah saudara, posisi anak dalam keluarga, dan lingkungan juga bisa menjadi faktor yang mempengaruhi perkembangan anak. Pada ibu yang menikah di bawah 20 tahun, meraka tidak memiliki pendidikan yang cukup tinggi sehingga akan menyulitkan untuk mendidik anakanaknya jika tidak memiliki pengalaman. Faktor sosial ekomoni yang rendah juga bisa mempengaruhi perkembangan anak. Anak yang terlahir dari ibu yang menikah dini kebanyakan memiliki sosial ekonomi yang rendah. Sosial ekomoni yang rendah berarti untuk memenuhi kebutuhan seharihari terutama gizi akan tidak begitu baik hal itu juga bisa menghambat pertumbuhan anak $^{9,10}$.

\section{SIMPULAN}

1. Terdapat hubungan antara pola asuh orang tua dengan perkembangan anak prasekolah pada ibu yang menikah dini .

2. Pola asuh orang tua pada ibu yang menikah dini atau dibawah 20 tahun sebagian besar menggunakan pola asuh permisif.

3. Pola asuh permisif dan demokratis pada ibu yang menikah dini di desa jabung memiliki perkembangan anak cenderung normal. Sedangkan pada ibu yang memiliki pola asuh otoriter dan penelantar perkembangan anak cenderung suspect. 


\section{KONFLIK KEPENTINGAN}

Tidak ada konflik kepentingan dalam penelitian ini.

\section{Referensi}

[1] BKKBN.2010. Pendewasaan Usia PerkawinandanHak-hak Reproduksi bagi Remaja Indonesia. Jakarta :Direktorat remaja dan perlindungan hak- hak reproduksi.

[2] BKKBN. 2012. Pokja Analisis Dampak Sosial Ekonomi terhadap Kependudukan. Jakarta : BKKBN

[3] Dewi, Devita kusuma. 2015. Tingkat keterpaparan Internet dengan Pekembangan Sosial Anak.Jakarta: Program Studi IImu Keperawatan, Fakultas IImu Keperawatan Universitas Indonesia.

[4] Eka sari, Hana. 2013. Pengaruh Persepsi Orang Tua Tentang Anak Dan Usia Pernikhan Terhadap Pola Asuh Anak( Study pada Keluarga yang Menikah di Usia Muda di Wilayah Rw 17 Desa Cigugur Girang Kecamatan Parongpong Kabupaten Bandung Barat. Bandung :Universitas Pendidikan Indonesia

[5] Hidayat, A Aziz .2013. Pengantar IImu Kesehatan Anak untuk Pendidikan Kebidanan.Jakarta :Salemba Medika

[6] KPPA (kantor pemberdayaan perempuan dan anak).2012. Data Pernikahan Dinitahun 2012 Kab Malang.Malang : KPPA

[7] Kusumawardani, DewiAriani. 2015. Hubungan Pola Asuh Orang Tuadengan Perkembangan Bahasa dan Personal Sosial Anak Pra Sekolah (3-5 Tahun) di $K B / T K$ Selaras Cita Malang. Tugas Akhir. Tidak Diterbitkan. Jurusan S1 Kebidanan FKUB, Malang

[8] Riskesdas. 2010. Riset Kesehatan Dasar :Riskesdas. Jakarta :Balitbang Kemenkes RI

[9] Riyadi, 2013 Asuhan Keperawatan pada Anak. Yogyakarta:Graha Ilmu

[10] Soetjiningsih. 2013. Tumbuh Kembang Anak. Jakarta: EGC 